\title{
Casting shadows of doubt: Perspectives of reputable journalists on fake news
}

\author{
Maria Monica A. Gonzales ${ }^{1 *}$, Elijah James D. Palaca ${ }^{2}$, Saimehen Lloid P. Iluis ${ }^{3}$, \\ Mary Ann E. Tarusan ${ }^{4}$ \\ 1, 2,3,4 University of Mindanao, Davao City, Philippines
}

\author{
Keywords \\ Mass communication \\ Case study \\ Fake news \\ Journalists' perspectives \\ Davao City \\ Received: 8 October 2018 \\ Accepted: 12 November 2018 \\ Published: 11 December 2018
}

\begin{abstract}
This study explored how three of Davao City's reputable and veteran journalists viewed fake news and what they perceived as its causes and consequences. Since fake news elicits public attention because of its role in international and national elections, problems have been attributed to it. From in-depth interviews with the participants, results revealed that they viewed fake news as fabricated, unacceptable, causing ignorance, and money-making. The causes were pointed out as anyone can do, deliberate and motivated, and for profit. They identified the consequences as negative but entertaining, leading to the generalized judgment of news and destructive. In conclusion, the effects of fake news must be understood by society because it affects everyone in a democratic society that engages every individual in every dialogue. The press and the public need to understand that fake news can come from anyone in the city, country, or world.
\end{abstract}

\section{INTRODUCTION}

Today individuals gather information or news from a lot of sources. There is the traditional media such as television, radio and print. There also arises the medium that challenges the existence of these tri-media, the social media. Undeniably, most people nowadays resort to social media for information. According to a survey conducted by the Pew Research Center in 2016, in association with the John S. and James L. Knightly Foundation, most adults from U.S. get their news on social media. "A majority of U.S. adults - $62 \%$ - get news on social media, and 18\% do so often" (Gottfried \& Shearer, 2016; Izhar, Baharuddin, Mohamad, \& Wan Hasnol, 2016; Polat \& Uluturk, 2018). It is evident that social media platforms are now considered by many as a source for news.

Since there are numerous sources for news disseminated on social media sites, one must still be cautious as to how accurate its information is. There are countless news items posted on social media sites and not all of these are true.
Fake news and false information also have their spotlight on these platforms. Fake news continues to spread worldwide. For Hetherington et al. (2005), the trust level of Americans in the accurateness and fairness of the delivery of the news dropped from 53\% in 1997 to $32 \%$ in 2016, due to the prevalence of fake news. Even in terms of perception of media freedom and independence, the numbers are continuously decreasing, with only $20 \%$ of the citizens of the Republic of the Congo saying their media was free in 2014. From a Gallup poll, only $14 \%$ of the citizens in Taiwan and Ethiopia had confidence in the quality and integrity of their media. It is considerable that the spreading of false information and misleading news has lessened public trust towards the major newspapers and broadcast stations. Some mediums are no longer seen as trustworthy, unlike in the past.

\section{Purpose of the Study}

This qualitative-multiple-case study aimed to showcase the knowledge and experiences of three carefully selected media practitioners who each work in the three major medi-

${ }^{*}$ corresponding author: Maria Monica A. Gonzales

†email: saimehenlloid@yahoo.com 
ums: television, radio and print. The research presents the opinions and understanding of these media practitioners, all veteran journalists.

\section{Research Questions}

Three questions were asked: First, how do the journalists view fake news? Second, what do they think causes the production of fake news? Third, what are its consequences?

\section{Theoretical Lens}

This study underpins on two theories, the Agenda-Setting Theory (McCombs \& Shaw, 1993) and the Gatekeeping Theory (Shoemaker \& Vos, 2009) The former has two base assumptions: first, the media do not reflect reality; they filter and shape it, and second, media concentration on a few issues and subjects lead the public to perceive those issues as more important than others. McCombs and Shaw posit that mass media exerts a significant influence on what voters consider to be major issues in a campaign. The basic building blocks of the theory are priming, defined as the media activity in proposing values and standards by which objects of media attention can be judged (McCombs \& Shaw, 1993), and framing, defined as the process of selective control (Communication Theory, 2011; Wijetunge, 2016).

Framing is defined as the process of selective control and is divided into two meanings: one, the way news content is normally shaped and contextualized, and two, the way the audience adopts to the frames so that they will see the world in the same way as everybody else. This process talks about how people attach to important things, the media only frames the news so that the public views it in a different way (Communication Theory, 2011).

In support, the Gatekeeping Theory, coined by German psychologist Kurt Zadek Lewin in 1943 (Communication Theory, 2011), was originally used in psychology but later entered the field of communication. Today, it is one of the essential theories in communication studies. The term "gatekeeping" is controlling or limiting access to something particular. It is, in a simple sense, blocking unwanted things. Here, the person or individual who decides what to block is called the "gatekeeper" (Communication Theory, 2011). In this theory, some information are disseminated to the public and some are blocked. The decision which information to be disseminated or blocked lies in the gatekeeper, which are the writers, publishers or editors of news items and information (Mishra, 2017).

\section{RELATED LITERATURE}

Despite the dearth of research on how fake news affects the career of journalists, the public's attention on its effects is wide. As such, studies or online articles related to the significance of fake news are synthesized for literature review.

\section{Definition and History of Fake News}

Fake news has already proven that it is not new. Until recently, there was only news, now there is "fake news" that Donald Trump used in his favor during his successful 2016 presidential bid (Montejo \& Adriano, 2018; Simmons, 2017). The term has been used countless times ever since (Allcott \& Gentzkow, 2017). Fake news, although recently resurfaced, has been around since the 19th century. Bending the truth for political gain is certainly nothing new as its technique in propaganda and its record of its uses stretch back to history. Octavian, of Roman stories, used a campaign of false information to help him achieve victory over Marc Anthony in the final war of the Roman Republic (Carson, 2017). In the Philippines, the first ever recorded case of fake news was during the 1896 Philippine Revolution when the United States faked a war to claim the rights of the country from Spain (Cabreza, 2017). Fake news is also described to be news articles that are intentionally and proven false, and could misinform its readers (Allcott \& Gentzkow, 2017).

Today, fake news still has the same meaning: fiction purposely made-up and presented as legit articles with the purpose of misinforming readers into treating fiction as reality (Chadwick, 2017). Further, he states via The Guardian that fake news presents a threat so serious that the longstanding codes of ethics of professional journalism should have a new obligation added: expose fake news as fake.

\section{Impact on Politics}

Fake News played a huge part during the 2016 elections in most countries. Be it in the international, national and global settings, the public, sometimes the politicians themselves, spread word about a certain candidate doing something that is obviously not favored by the rest of country, making the rest of the public think twice about voting for that certain candidate. Although different in terms of country, the effects of fake news are the same (Allcott \& Gentzkow, 2017).

\section{The International Scene}

Globally, most countries have had their fair share of fake news reports. It started from the Roman emperor Octavian to the 1828 US election where Andrew Jackson's people started a rumor that John Quincy Adams had procured an American girl to satisfy the Tsar (Seidman, 2008). As a result, a mob stormed the White House during Jackson's 
inaugural celebration. Historians record that fist fights occurred, leading to damage to property. Fast forward to the 20th Century, where the British government used a form of fake news to motivate the populace against Germany, called "The Hun" in the first World War (Carson, 2017).

But among all of the countries that produced famous fake news, the United States of America takes the spotlight. The resurgence of the term "fake news" in the US was all because of Donald Trump, now the current US President. Trump declared war against journalism and its practitioners. In Donald Trump's perception, the mere act of reporting antiTrump news is held up as evidence of bias, leading to journalists being called the antagonists ("Trump's War on Journalism" ). The so-called "war" came to be when Trump accused CNN's Jim Acosta as "fake news" and proceeded to ignore the journalist during his (Trump's) first conference as president-elect (Carson, 2017). Since then, the now President has been calling out major media outlets multiple times a week for being "fake news" via his Twitter, with CNN and the New York Times as main targets.

Following the 2016 US elections, more false stories circulated on social media. Recent evidence shows that $62 \%$ of US adults get news on social media (Gottfried \& Shearer, 2016). The most popular fake news stories were widely shared on Facebook than the mainstream news stories (Silverman \& Singer-Vine, 2016); many people who see fake news stories report that they believed in them (Silverman \& Singer-Vine, 2016); also, according to them the most discussed fake news stories often sided with Donald Trump over Hillary Clinton. By analyzing the facts, numbers would suggest that Donald Trump wouldn't be elected president if it weren't for the influence of fake news (Grusin, 2017).

\section{Fake News on the National Scene}

Like many countries in the world today, the Philippines is deluged with fake news. Fake news is not relatively new to the Filipinos as Cabrere in 2017 claims. The first ever recorded case of fake news in the country was during the 1896 Philippine Revolution. After the revolution, fake news faded, hiding in the deep corners of traditional media until it resurfaced during the 2016 May Elections. Fake news has become a problem in the country as it sprouts from every direction, converging mainly in social media. One example is when Senator Antonio Trillanes, a known critic of President Rodrigo Duterte, was arrested for drugs and for supposedly accepting major bribes. The senator's team already confirmed that it was all made up but the public remained unconvinced, especially those who supported Duterte (Clark, Arsenault, Dawson, \& Wolf, 2017).
In conclusion, fake news plays a huge role in the global political landscape, frequently cited as an influencing factor in the Philippine and US elections (McCombs \& Shaw, 1993). Maria Ressa, Rappler's Chief Executive Officer, already stated in 2017 that democracy is dead and what we're seeing is an exponential growth of propaganda networks that hijack what used to be called Democracy (Arsenault, 2017).

\section{Creating Fake News}

In its purest form, fake news is literally "fake news" as in made-up, made to look like real journalism and to attract maximum attention, and with it, advertising revenue (Gray, 2017). Thus anyone with a laptop or some kind of gadget and internet connection is able to post false information and share it on different social media platforms. During the rise of the fake news trend in 2016, the public saw small groups of people taking advantage of social media who created hyperbolic articles around a major event; in this case, the elections (Gu, Kropotov, Yarochkin, Leopando, \& Estialbo, 2017). Due to the rise of social media, delivering fake news has become as easy as delivering real news, even quicker. Facebook leads the charge as the "biggest driver of traffic to" as it is connected to most websites (Silverman \& Singer-Vine, 2016). The creators of the false article would start sharing it and people would start clicking. Sometimes, the creators would purchase Facebook accounts which they can then use to go online and drop links to the stories on their websites.

People tend to spread false information for attention, either personally or online. With the use of social media, individuals can easily spread false information, and as most people tend to check their phones right before leaving bed in the morning, it will be the first thing they see in some cases (Shao, Ciampaglia, Varol, Flammini, \& Menczer, 2017). Using Facebook as the driver, people who make fake news tend to go off; they make a profit by putting the fake news articles in their sites with ads from Google so they can make a penny out of every click. Using Facebook is a benefit since 1.8 million people log in everyday around the world (Silverman \& Singer-Vine, 2016) Most fake news is hosted on websites that often follow design conventions of online news media with titles such as "Civic Tribune" and "Life Event Web" for the US and "Adobo Chronicles" in the Philippines to give resemblance of legitimacy; these stories are predicted to travel across every social media platform (Chen, Conroy, \& Rubin, 2015). With the clicks made on a certain "report", a man running a string of fake news sites from Los Angeles told the National Public Radio that he made as much as US $\$ 30,000$ a month from advertising. Pro-Trump fake news 
sites operated by teenagers in Macedonia totaled up to 100.

\section{Fake News in the Modern World}

The United States and the Philippines are not the only countries affected by the spread of fake information as fake news has become a worldwide phenomenon today with more media outlets worldwide publishing false information. Although not every part of the world observes this behavior, cases were found by the British newspaper The Guardian in 2017 and included Germany, France, Myanmar, Italy, China, Brazil, Australia and India. Fake news became even more popular with the help of the internet, specifically social media sites which rose to prominence in 2004. Before the advent of the internet, it was impossible to publish fake news and gain an audience that could be monetized due to three reasons: distribution and cost, audience and trust, and law and regulation (Carson, 2017). But since the rise of social media, the fake news issue has grown to considerable lengths attracting the attention of the United Nations. The fake news issue has become a global topic of concern (Graber \& Dunaway, 2017).

With this, the United Nations made a declaration on monitoring freedom of expression. Due to the deliberate spread of fake news, the probability of both threats and violence against journalists increased, lowering the public's trust and confidence and ultimately misleading the population by blurring the lines between fake information and factual media (Mail Online, 2017). Most UN experts did not point to the country being stated in the declaration but it did point out the Twitter feed of current US President Donald Trump due to his constant posting against "fake news media" (Mail Online, 2017).

Further, fake news' rise has raised a red alert in every country worldwide as it can harm individuals' reputations, intrude into their privacy, provoke violence, discrimination and/or hostility against social groups (Mail Online, 2017). To summarize, fake news is getting bigger by the second resulting in dire consequences not only for an individual but for the world.

\section{Scope and Limitations}

The researchers limited the interviews to three professional journalists from different media industries; print, radio, TV, social media, and other experiences and viewpoints, specifically the hows and whys fake news are made. The three participants were chosen from the list of available journalists within Davao City. Only those aged 30 and above were taken into consideration based on Gover (1996) assessment that people are generally self-aware and willing to change when they are more mature. The researchers did not fo-

cus on people fabricating fake news as the main focus of the study were the journalists' experiences.

\section{METHOD}

\section{Research Design}

The qualitative approach using the case study was used to gain the perspectives of three professional journalists currently working in their different media platforms i.e. print, radio and TV. The researchers did not specialize in a field since fake news affects every platform including social media and the internet.

\section{Research Participants}

The participants of this multiple case study were three professional journalists from print, radio, and television, currently working, who had already established honesty, credibility and integrity with the public. Participants had a college degree in mass communications or a related course; had experience within his/her platform; learned on the issue of the spread of fake news, and aged 30 up.

\section{Information Sources}

Data were collected through in-depth interviews, and depended on the willingness of the participants to be interviewed. Each participant was asked for an interview at least one week prior for proper scheduling. Furthermore, the questions were given to the participants one week before the initial interview for them to remember specific events in their respective lives. The interviews ranged from fifty minutes to one hour and a half.

\section{Conduct of the Interview}

The researchers undertook the following steps: research and finalization of names and ages of the candidates; personal request, in the form of initial feelers with the selected individuals; submission of approval for added legitimacy; and finally the actual interviews. No time-frame was observed for the interviews.

\section{Ethical Considerations}

Along with the conduct of interviews for this research, the participants were given code names. This safeguarded them from threats of some individuals which might be triggered by the information revealed in this research.

\section{Data Analysis}

The data gathered in this research were subjected to Thematic Analysis. For Renner and Taylor-Powell (2003), Thematic Analysis is grouping the gathered information or data 
into themes which may have either evolved directly from the research questions and pre-set even before the beginning of data collection or emerged naturally from the data during the conduction of the study.

\section{RESULTS}

This study focused on the perspectives on fake news of three reputable journalists and broadcasters from different mediums (radio, TV and print).

\section{Mark Broadcast Career}

Mark (pseudonym) is currently a news anchorman in a TV station in Davao City. His broadcast career started in 1993 when he first came across television. Although in the TV business, Mark also did radio work while still on TV, where he was in-charge of delivering the news in the AM format. Mark has also tried writing a column for a local newspaper. While being adept in all formats, he decided to concentrate on TV as it was his "first love" when he came to the broadcasting business. All in all, Mark has been in the media industry for about 24 years and still counting.

\section{Perspective on Fake News}

As Mark stated, fake news is existent, fabricated, mainly press releases with lies, and rampant. Even before the presidency of former Davao City mayor Rodrigo Duterte, fake news was already common by spreading news about death hoaxes of some of the most well-known people in the country and the world; examples being Andrew E., Sharon Cuneta, and Dwayne "The Rock" Johnson. He added that netizens aren't mature enough to dissect information.

Fake news is non-existent or fabricated news. Some fake news is used to discredit or destroy a person. There are also stories that are true but lousily written.

Mark, himself, checks the link or sources as some sources are questionable especially in social media. These are usually websites made to look like legit news companies like CNN, ABS-CBN, or GMA but are not actually connected or part of the said media companies. If Mark can't find the source, he uses the list of fake news sites provided by the National Union of Journalists in the Philippines. In their line of work, when they see something newsworthy on social media, they would immediately contact the one who originally posted it in to ask permission to use the content and broadcast it in their network.

\section{Causes of Fake News Production}

Mark also believes that the motives behind the production of fake news are to discredit the person, to create chaos among the public, and to cause fear to everyone. But to- day, most fake news are used to taint the image of a single person. Legitimate news companies aren't really affected by the spread of fake news; those vulnerable are the people who aren't mature enough to understand the real situation or the reason behind a post. That's why Mark believes that education is very important because nowadays, the internet is no longer used mainly for entertainment. People involved in the media business aren't just there to entertain, but also to inform, educate and persuade. Mark added that multimedia also contributes especially to social media sites as they have a huge impact on the perception and education of the young. Although adults are subjected to fake news, young people are most likely to be vulnerable. Sharing only news that fit their facts.

So if fake news proliferates then our netizens, especially the young ones, they don't know how to dissect the information, they will be telling stories of lies or those that are fabricated which they get hold of. The effect is they will look stupid in front of their friends.

In Mark's network, there are no limitations as long as what they are saying is true.

We are for sensational stories, but we do not sensationalize stories. We must not be limited, because when you tell the truth, there's no limit.

Mark's network follows an ethics manual created by the company. It is, as he described it, their bible and will always be in the office especially when deciding what to broadcast. If they have doubts about a certain report, they would use the Bible to see if there are any violations. Aside from the seminars and standards they attended at the National Center for Investigative Journalism, and the seminars held by the NGOs about responsible journalism, they have their company manual to follow. Mark said that as a reporter, you have your own gut feeling or instinct about a certain news story, but every story they write or broadcast needs to be cleared with the handbook guidelines. These standards, and also the conscience or instinct of every media practitioner will not help in exterminating fake news, but will at least minimize the problem.

It might minimize maybe, but it would not eradicate. You know social media and worldwide web. We can't just eradicate fake news. Think before you click.

Mark said that social media is worldwide and it will not be easy to eliminate fake news from the equation. These days, copy-pasting from different sources and accompanying it with a story that's fake makes it look credible. 


\section{Consequences of Fake News Production}

There was, of course, an instance when Mark fell victim to fake news. The news about Mount Apo burning; when some friend told him he had photos of the incident which he then sent to Mark who posted it on social media; only to find out later that the photos weren't the actual Mount Apo. So he ended up deleting the post and giving a public apology.

Mark continued that the relatability of a news story to the people is one of the reasons why fake news keeps on spreading. If an article favors their interest, it is an automatic share without checking its credibility. Mark believes that it should not be a reason to tolerate fake news; it is also a responsibility of the media to help minimize the production of fake news. For instance, in Mark's company, they broadcast the fake article to let the people know that it is, in fact, fake.

Even if we're just ordinary citizens, let's also be responsible. Let's be realistic. Let us not be clouded by our own selfishness, our own purpose, just because we like the story, it favors us and we like it, ok. I mean, it's always about the truth. Journalism is always about the truth. It's facts.

Fake news affects the media industry in a sense of a person using the company's name in any way.

As I see it, the media company will not really be affected. It's more on sticking to our editorial content which we know is right. We'll take a stand for what's true and factual. I don't think it will affect our credibility or our ratings or the popularity. Because eventually, people will know if what they're talking about is false.

Mark believes that the only positive effect of fake news is for entertainment. It gives him laughter every time he reads an article that's fabricated. But seriously there is no positive effect.

It's all negative, no positive effect whatsoever. You'll be amused and entertained. You'll just laugh at the stories but you cannot gain anything from lies.

Talking about how legitimate journalists cope with the problem, Mark considers it a struggle because there are media personalities and institutions that are paid.

Lots of challenges. You have to understand that just because you're legit, you're clean. Just because you're connected with a trustworthy network or media institution, you're already ok. But if you yourself are not true to what you're doing, you're a bad influence. You'll affect others. So it's a struggle.

Mark also mentioned that the network he is working for is $100 \%$ clean, stating that they have problems of their own to solve. One way to solve those problems is to accept there is a problem. But good to say that Mark's company has tried its very best to minimize this problem. Personally, Mark copes by sticking to the truth, values and ethics manual.

In spite of coping, Mark also had his fair share of discouragement in his field of work, because, as he said, it's a challenge for him and for the rest of the journalists to compete with fake news. It's like its good over evil. Right versus false. So we'll just do our best. We're challenged to make a very good story, an interesting story to which people can relate, so that those who see and believe in legitimate information, in reputable media institutions, won't see any more fake news. But despite the discouragement, his motivation to continue his work is because he loves his job stating that "being a journalist is not a job, it's a vocation. Public service". Moreover, Mark believes that people aren't educated enough to identify fake news citing the youth today as the best targets for fake news as they are still gullible.

Finally, Mark isn't very sure about the chances of completely abolishing fake news, at least not in his lifetime. He even believes that laws against the production of fake news are lacking. In his view, education is the only thing that will help combat fake news. Education for citizens, websites. In their "Think before you click" campaign; they urge the people not to share everything they find on sites. But for Mark, it is still up to the public to join the call, to listen, to dissect the information given. Mark simply believes that education will be the key to fight fake news.

\section{Bobby Broadcast Career}

Bobby (pseudonym) started in the media industry when he was still in high school 30 years ago in 1987. With his first love being radio, he became a FM disc jockey in a local radio station. He then transitioned to newspaper reporting having described the transition as "growing up". He shifted to TV reporting as a TV anchor at a local news station. He left the TV medium and is now an anchor of an AM radio news program. All in all, Bobby has tried all the mediums of journalism be it print, radio and television.

\section{Perspective on Fake News}

Bobby, with all his experience in the industry, believes that if fake news continues spreading, what would the people believe? As he puts it, fake news is really "fake" news, always not true; always hearsay. How can the public get their educated information if people themselves continue to spread fake news? The public will become ignorant of what is really going on.

Fake news, for me, is unacceptable, it's something that would really divide or destroy the country. Because if you continue to sugar coat everything just to be able to advance your own interest, there will be no progress. We're always 
spreading controversies which are not true, which will result in separation from the truth.

He, himself, hasn't encountered fake news face-to-face, but Bobby has already seen people from the public who make fake news. As quoted, it's very anti-progress since people fight a lot but they do not know they are being manipulated and misled. He also stated that a lot of lives are ruined because of fake news. Although he's seen other media personnel make fake news which he describes are "irresponsible", he has no other personal experience regarding fake news.

\section{Causes of Fake News Production}

Bobby, in his years, believes that fake news indeed has motives. Be it for a certain politician you wish to promote or something else, he believes fake news doesn't just develop out of thin air without a reason.

Why would you spread fake news if you don't have a motive? This will affect the entire population as misinformed people will remain ignorant, they can't move forward, they can't see progress in everything that you hear in other people because you don't know the true scenario.

Bobby said that it doesn't affect him and his network in news production, as they really see to it that their news is a hundred percent true. They can easily detect a news story that's fake or hearsay. If they think a story is lacking, they'll conduct an investigation as his company has guidelines in making news so that the first time a person will read it, he/she will automatically know that it's not fake.

Bobby also believes that one of the factors in creating fake news is its limitations. He cites other media personnel who are unprepared, uneducated, and untrained to be the source of real news; for this reason, fake news becomes their comfort zone because they don't know how to investigate or get facts. He said that having professionals who are welleducated, well-trained, and well-disciplined will decrease the chance of fake news.

Bobby also mentioned his company's "bible" which contains the guidelines for making news. The people there would read the bible once or twice in a week to get a hold of the proper ways of making news and not just to broadcast fake news. It contains their rules, he compared it to a home wherein you have your own set of rules to make things in order; if they don't set the rules, everything will be in chaos, with rules, you can easily get rid of the chaos.

Bobby said that people have particular needs that might lead them to spread or create fake news, but this will only happen if the organization is weak, where people do not follow standards. He has mentioned that people look up to the media for their daily information.

\section{Consequences of Fake News}

Bobby believes that media practitioners spreading fake news have a sweeping effect on the media industry. He mentioned other journalists protecting other politicians for their own gain. Whenever a mainstream media company produces news that doesn't favor their view, they'll automatically mark it as "biased". "Biased" because they do not understand the basics of news gathering, writing, or broadcasting. He said that people who develop fake news only come out in social media because that's where they're given freedom to do so, seemingly forgetting the golden rule of separating news from opinion.

For Bobby there are no positive effects of fake news because he believes that each piece of fake news will result in a sweeping effect regardless of the medium, be it radio, tselevision or print. He also said that there are some people who cannot be stopped from spreading fake news. All he can do is stay on track and to stay on what he believes is right. All he could say is that the public shouldn't be like those people who spread fake news.

He had times where he doubted his profession, because in just his second year he already saw the illness of the industry in the form of corruption. Since then, he did his best not to be part of the media that makes fake news. All he wants to do is to remove the scalawags in the industry as it will not benefit the media practitioners. He just wanted to think about his love for his job, his life. It was in the media where he grew old, ever since his 17-year old self started training for FM radio. All he wants to do is to go out with his name respected rather than crumpled upon.

Bobby believes that people will identify fake news easily in the future. His only concern is the younger generation who still do not know the difference between fake news and real news, especially the young ones who aren't educated about this. He also hopes that fake news will fade but slowly.

For as long as politics has a major role in media, it would be an uphill climb, but never lose hope.

He said that he will never go down to the level of producing fake news for the sake of one person or group. He believes that due to the lack of education in society, people are easily misinformed. Other than education, Bobby believes that people also need values because today's youth no longer respect the previous generation.

Bobby said that most people share information on Facebook whether real or not as long as it contains information on their beliefs. Clearly propagating or sharing fake news indirectly becomes viral, spreading like wildfire. It's the simplest thing to do to spread fake news without knowing it's wrong. 
You don't have to be part of the media to be responsible. Even an ordinary person should know his responsibility. Bobbly also believes that in our times, people should know the sources before sharing it. They should not engage in any debate against someone who's speaking the wrong things because it will only fuel more their desire to spread fake news. He states that society should nurture the minds of the youth for them to differentiate factual from fake.

\section{Jocelyn Broadcast Career}

Jocelyn (pseudonym) has been the Editor-in-Chief (EIC) of a newspaper company since 2003. She is part of the administrative department. Her main job is to direct the main course of the newspaper; on what to cover, and where they are to cover the events of the day.

\section{Perspective on Fake News}

Jocelyn believes that fake news already existed even before radio. In her idea, the first ever documented case of fake news was Orwell's book "War of the Worlds" which was aired on the radio at its time, where it caused problems to the community with people thinking that the world was ending. Today, she contends that aside from fake organizations, fake news can also come from well-established, mainstream media organizations.

Fake news doesn't really have to come from a fake organization. Sometimes, even mainstream media can publish fake news. Not because they want to publish fake news, but because some of the sources of their stories are not really precise.

\section{Causes of Fake News Production}

She believes that writers do not get the facts right, which causes the story to go awry, that's why when the news goes live or gets published, the story won't be the same. Jocelyn says that it is not the writer's fault as fake news comes from the consciousness of people who stumbled upon social media.

Unlike mainstream media, social media do not have gatekeepers. Whatever you write on social media, you become your own publisher.

She said that it is one of the main things that separates mainstream media and social media; besides as a platform, social media is prone to alternative news, for instance, a person can make his or her own personal website with ease or maybe a person will be called by a company and the company will pay for the content.

If it becomes business, it doesn't have to be news as we, journalists, perceive it. Because of the internet, the practice of paying people to provide content, then that becomes very prone to fake news.

\section{Consequences of Fake News Production}

She believes that internet trolls worsen the situation, as they go online to wreak havoc across the worldwide web with their fake news and facts, getting into debates with other people and twisting their words. Jocelyn added people should be aware of trolls especially since cybercrime is prominent.

You can really be charged with libel which carries with it twice the penalty in print. If you're being charged for libel in social media, it's worse.

Moreover, Jocelyn had experience with fake news that led her to view fake news that way; "It wasn't called fake news back then, but sometimes, you have to sift through the stories which you think is propaganda which is actually fake news but on the other side of the fact".

Getting more sources helps you identify what fake news is. According to her, we have skills. Most media companies are doing trainings on how an individual can check whether the news being shown are news or not, fake or not. She believes the youth play a huge role in spreading fake news as they don't bother to check the sources or links, they just share it. Jocelyn also believes that there are motives as to why people are making/spreading fake news. She mainly cites the paid media content providers.

You're facing a computer basically, so you can do whatever you want. If you want to get paid, you get paid for like two hundred and fifty pesos for seven hundred words and you do the blog then you get paid.

Nevertheless, Jocelyn believes the effect of fake news depends on the readers. According to her, since the readers of her newspaper are so-called A and B sections, meaning their readers are lawyers and government officials, she is confident that her news won't be read or misinterpreted as fake because their news is verified. "Well-vetted" as she would describe and it passes through the standards of editors, and they don't mainly rely on the internet for sources.

As for the limitations and standards of particular media institutions, Jocelyn believes this does not really affect the production of fake news; how they define fake news should lead them to be $100 \%$ accurate, so obviously, the limitations won't contribute to ss fake news.

The way we define our kind of news should lead us to being accurate.

She added that the perception of people of the media companies, especially TV stations, is they are biased for a single person, e g. a politician. But it is not like that because it depends on the view of the people, but as much as possible, 
every journalist tries to follow the ethics of journalism. One thing for sure, other people wouldn't question the integrity of veteran journalists since they've been around for so long. Journalists stay on forever. We've seen how the city has grown, we've met a lot of politicians who were really very confident to stay in the position for so long but who are now private citizens and we're still journalists, so it's different. For standards, Jocelyn mentioned that they have an ethics manual in their company since 2003. They did their own style sheet and they follow the Associated Press style book on how to write their stories.

We learn from our experience. You can teach ethics as much as you want in school but at the end of the day, it's really who you are as a person, as a journalist. It's your conscience really talking to you. It depends on who you are. But of course, there's a general rule. We have in-house memos to check the parameters of our journalists.

With the talk of minimizing fake news, Jocelyn added that it is hard to determine whether or not their standards can help to minimize the production of fake news because they, themselves, cannot control the public who are the consumers of information, especially since a lot of people are degrading other people.

A lot of people just do it and it's fun for them. Talking against other people; demeaning or saying really bad things. It's okay with them, because they don't have that kind of conscience, maybe.

On the other hand, Jocelyn believes that it's not the need of the people towards news content that causes fake news production; rather, it's the situation where people would see things as something against a party or group. Instead of dissecting the information, the people will directly judge the report or story.

Anything critical, people think that it's against the government. It's a trend already. It's really how we consume our news stories.

She is optimistic that there are still people who read news- papers and don't rely on social media for information, especially the decision makers. First world countries are downsizing their newsrooms and transferring online which they call "integrated newsroom". But for the developing countries, newspapers are still there because advertisers are more inclined to advertising through print.

It terms of the effect of fake news to the print industry, Jocelyn believes that it's rather a challenge for journalists to be mindful of what they write, to get as many sources and to do their job well.

When talking about the positive effects of fake news, Jocelyn's answer is directly "no".

Fake news is fake and how can something wrong be so right. It only destroys people. It destroys how people look at the government, for instance.

Jocelyn also believes that legitimate journalists cope with this problem by being better, by being accurate, by talking to people. If they write their stories, they should make sure first that its sources are credible stating "It actually helps the profession. It makes us better."

Jocelyn also believes that not everyone is completely aware of the dissemination of fake news and that society needs proper education. She views that this kind of topic needs proper discussion, debate, talk of the happenings around a community and the proper use of the web. She says that most of the people don't know how to verify news content because most of them automatically believe the first thing they'll see on the internet. But if there was proper education, the chance of people finding out for themselves would be higher than before.

Hence, she believes that although fake news will never be abolished, but it can be at least be minimized.

No, especially because we love chismis(gossip) and it's human nature to really just go wild.

She continues to do her work, reaching out to different schools and students to teach them how to spot fake news which might help in minimizing its dissemination.

TABLE 1. Journalists' view on fake news

\begin{tabular}{|c|c|c|}
\hline Pseudonym & Core Ideas & Themes \\
\hline Mark & $\begin{array}{l}\text { Fake news maligns people leading to the discrimination of the public. Fake news is non-existent news; } \\
\text { used to attack a person or a group. }\end{array}$ & Fabricated news \\
\hline Bobby & $\begin{array}{l}\text { Fake news deceives the public into believing something else. Due to fake news, the country is contin- } \\
\text { uously divided into people setting up groups against other groups. }\end{array}$ & Unacceptable \\
\hline & With fake news, the public will be forever ignorant of what is happening and what has happened. & Causes ignorance \\
\hline Jocelyn & $\begin{array}{l}\text { People get paid for news content so it doesn't really have to be legit news. As long as a hired person } \\
\text { posts something, it's considered news by his/her employers. Because of this business of paying people } \\
\text { to get the news content, the information/facts will be jumbled which will lead to fake news i.e. having } \\
\text { an article with zero to none credibility. }\end{array}$ & Makes money \\
\hline
\end{tabular}


TABLE 2. Causes of the production of fake news

\begin{tabular}{lll}
\hline \hline Pseudonym & Core Ideas & Themes \\
\hline Mark & Fake news can come from anyone, adults or even the youth. Due to the lack of education, they & Anyone can make fake news \\
& $\begin{array}{l}\text { will remain ignorant as they cannot dissect the information given thus giving them false ideas } \\
\text { about a certain topic. }\end{array}$ & \\
Bobby & $\begin{array}{l}\text { Fake news is spread with motives against a single person or a group of persons. The effect of } \\
\text { spreading fake news is the ignorance of the public. All they hear about is hearsay and not the }\end{array}$ & Deliberate and motivated \\
& whole scenario. & \\
Jocelyn & $\begin{array}{l}\text { Anyone can be a tool for spreading fake news as long as he or she has a stable internet con- } \\
\text { nection and a computer. }\end{array}$ & For profit \\
\hline \hline
\end{tabular}

TABLE 3. Consequences of the production of fake news

\begin{tabular}{lll}
\hline \hline Pseudonym & Core Ideas & Themes \\
\hline Mark & $\begin{array}{l}\text { Fake news is negative as it cannot give anything but lies to the public. Journalists, on the other } \\
\text { hand, view it as negative and entertaining at the same time. }\end{array}$ & Negative but entertaining \\
Bobby & $\begin{array}{l}\text { Due to the rise of fake news, the public no longer knows what is true and what is fake thus } \\
\text { giving them the idea that all of the journalists and media industries are liars and distributors } \\
\text { of fake news. }\end{array}$ & Generalized judgment of news \\
& $\begin{array}{l}\text { Fake news destroys everything it touches. It destroys the trust of the people and it destroys } \\
\text { things like the government. As of today, the country is divided into believing other things. }\end{array}$ & Destructive \\
\hline \hline
\end{tabular}

\section{DISCUSSION}

Summing up, the participants view fake news as something destructive not only to people but to society. Basically, fake news destroys or maligns an individual simply by the wrong information that is inserted on the story or news. This outcome attests to the statement "the rise of fake news has indeed raised a red alert globally as it can harm reputations of every individual, their privacy, provokes violence, discrimination and/or hostility against social groups" (Mail Online, 2017). It is unhealthy for society because it distorts the truth which causes the dissemination of false information among the public. There would be a mass circulation of falsehood going around not only in proximate areas but also around the world. It would be the global topic of concern (Graber \& Dunaway, 2017).

Hence, it would be harder to stop this kind of problem especially that most fake news exists on the internet. As Mark mentioned, it is unlikely that the production of fake news will be eradicated because most people log on to the worldwide web from which stories and news items are published often published anonymously.

The participants highly believe that there are motives behind the production of fake news. All of them believe that the dissemination of fake news has something to do with political inclination. They believe that some media companies or institution, or even media practitioners themselves, are politically influenced to write stories or publish news that are in favor of a particular party. From the Roman history's Octavian campaign Carson (2017), Shao et al. (2017) to the distortion of the 2016 US Presidential elections (Chadwick, 2017) to the Philippines own recent elections, fake news indeed plays a huge role in the landscape of politics not only on the local and national scope but also on the global range (Mail Online, 2017). These media institutions are often compensated with amounts of money to produce fabricated news items and stories. Some of the information these paid content providers produce are stories which targets or attacks an opposing side. From this viewpoint, one participant believes that these motives will affect those individual who are not mature enough to understand the situation or those who do not verify the legitimacy of the story, first. If people, especially the young ones, would not dissect information, they would share false data or even tell lies just because they shared information which is a lie itself. People will not only contribute to the dissemination of fake news but it will also affect their perception towards the structure of a story or news. It will be harder for them to identify the legitimate stories from the fake ones. This would parallel to one of the definitions of fake news as made-up stories that could misinform people (Allcott \& Gentzkow, 2017; Chadwick, 2017). As how Bobby would have mentioned it, people who are misinformed will continue to be ignorant. There will be no progress because these people would only rely on what they would hear from other people without bothering to know the truth behind the story. For Bobby, the dissemination of fake news is truly anti-progress.

Although, he and one other participant still believe that it is unlikely that legitimate media entities would fall for these falsifications. As how they would mention, media practitioners would easily identify or spot whether a story is fake or not. Especially that all three of the participants have their individual ethics for journalism which serves as their ba- 
sis for standard in writing a story. The participants from the television, radio and print medium call this their ethics manual or bible, in which they always review when they write stories they're not sure about. They also said that everyone from their company is provided with the same ethics manual they obtain. Therefore it is likely that other media practitioners, not only from their institution but also from other media organizations, are knowledgeable enough of the standards and structure of news stories.

Nonetheless, the participants somehow still felt discouragement at some point in their field of work because of public judgment. People would accuse the media as biased when publishing or broadcasting a particular story. Even in the US, President Donald Trump himself accuses certain media outlets and media practitioners as bias in reporting news “Trump's War on Journalism” 2017. But this didn't affect the participants as much, for each of them has their own personal motivation that keeps them going despite of it all. They consider themselves dedicated working individuals who simply love their job that they would not sacrifice it in exchange of gifts and any amount of money. In fact, this struggle as they all would consider, is actually challenging them to become even better professionals of their own field. Jocelyn believes that this particular struggle all the media are familiar with only challenges journalists to be mindful of the stories they are writing and to be accurate as much as possible; to gather as much sources and do the job well. The following, she said:

Thus, the participants each have their own ways to, if not eradicate, minimize the production or dissemination of fake news. All three of them similarly said that education is the best way to minimize this problem. Being educated enough will make a mature person out of every individual, and that will lead to a deeper understanding of situations that occur in the society.

\section{CONCLUSION}

The public is now beginning to criticize fake news. Plans on getting rid of fake news by focusing on the moral behavior of media practitioners have been made, or attempted. To institutionalize it, however, the support of institutions is needed in the total, humanizing process of building relationships between the media and the public.

Some issues are observable and noticed like the boycotting of major media companies, the people's lack of faith in today's media, the lack of ethics and professionalism, and the questioning of broadcast media as a model for today's youth. The quality of journalists is being questioned worldwide. The facts that challenges everyone is that the production of fake news can come from anyone with a computer and stable internet connection and the lack of support from the government when the government itself produces fake news. It is said that the media, or press, are considered as the fourth branch of the Philippine government. However, the government officials are giving the public ideas that the media is totally biased as long as the views of the media do not fit the views of the higher-ups. This can be interpreted as an attack since the media is pointing out irregularities of the government, both in the past and in the present. Of course, officials would try to protect their image. But, with them saying that media is not entirely true, the public will automatically question the industry.

What is needed in the country, specifically in Davao City, are experts with a good sense of public service who will create smart and knowledgeable media users, as this type of journalists have already learned about fake news and their credibility can influence people to think more intelligently.. Even if trainings and knowledge of fake news have been spread throughout different locations in the city and the country, it is still necessary to develop interest and awareness of fake news. A smart society is the key to minimizing the spread of fake news.

\section{REFERENCES}

Allcott, H., \& Gentzkow, M. (2017). Social media and fake news in the 2016 election. Journal of Economic Perspectives, 31(2), 211-36. doi:https://doi.org/10.1257/jep.31.2.211

Arsenault, A. (2017). 'democracy as we know it is dead'. Retrieved from https://urlzs .com/h8e5U (Accessed on 14 April, 2018)

Cabreza, V. (2017). Fake news also hounded 1896 Philippine revolution. Retrieved from https://urlzs.com/WPt4x (Accessedon 15 June, 2018)

Carson, J. (2017). What is fake News? Its origins and how it grew in 2016. Retrieved from https://urlzs.com/adkVJ (Accessed on 15 August, 2018)

Chadwick, P. (2017). Defining fake news will help us expose it. Retrieved from https://urlzs . com/uQ6Mg (Accessed on 14 Apiril, 2018) 
Chen, Y., Conroy, N. J., \& Rubin, V. L. (2015). Misleading online content: Recognizing clickbait as false news. In Proceedings of the 2015 ACM on Workshop on Multimodal Deception Detection, Beijing, China.

Clark, D. W., Arsenault, J. A., Dawson, J. W., \& Wolf, E. J. (2017). Method, system and apparatus for handling a request for a media-over-packet communication session. Retrieved from https://urlzs.com/CMtHv (Acessed on 17 August, 2018)

Communication Theory. (2011). Gate keeping theory. Retrieved from https://urlzs.com/mUSVR (Accessed on 16 July, 2017)

Gottfried, J., \& Shearer, E. (2016). News use across social media platforms 2016. Retrieved from https://urlzs . com/FMWLG (Accessed on March, 30, 2017)

Gover, M. R. (1996). The embodied mind: Cognitive science and human experience. Mind, Culture, and Activity, 3(4), 295-299. doi:https://doi.org/10.1207/s15327884mca0304_9

Graber, D. A., \& Dunaway, J. (2017). Mass media and american politics. Washington, D.C: Cq Press.

Gray, R. (2017). Lies, propaganda and fake news: A challenge for our age. Retrieved from https://urlzs. com/o7rHZ (Accessed on 1 February, 2018)

Grusin, R. A. (2017). Donald trump's evil mediation. Theory \& Event, 20(1), 86-99.

Gu, L., Kropotov, V., Yarochkin, F., Leopando, J., \& Estialbo, J. (2017). Fake news and cyber propaganda: The use and abuse of social media. Retrieved from https://urlzs.com/o7rHZ (Accessed on 5 July, 2017)

Hetherington, M. J., et al. (2005). Why trust matters: Declining political trust and the demise of American liberalism. New Jersey, NJ: Princeton University Press.

Izhar, T. A. A., Baharuddin, M. F., Mohamad, A. N., \& Wan Hasnol, W. M. H. (2016). Using ontology for goal-based query to evaluate social media data. Journal of Advances in Humanities and Social Sciences, 2(2), 108-118. doi:https://doi.org/ 10.20474 /jahss-2.2.5

Mail Online. (2017). Un experts express concern about growth of 'fake news'. Retrieved from https://urlzs .com/CvkV8 (Accessed on 16 September, 2018)

McCombs, M. E., \& Shaw, D. L. (1993). The evolution of agenda-setting research: Twenty-five years in the marketplace of ideas. Journal of Communication, 43(2), 58-67. doi:https://doi.org/10.1111/j.1460-2466.1993.tb01262.x

Mishra, P. (2017). Age of anger: A history of the present. London, UK: Macmillan.

Montejo, G. M., \& Adriano, T. Q. (2018). A critical discourse analysis of headlines in online news portals. Journal of Advances in Humanities and Social Sciences, 4(2), 70-83. doi:https://doi.org/10.20474/jahss-4.2.2

Polat, S. O. O., F., \& Uluturk, A. S. (2018). Hate speech in Turkish media: The example of Charlie Hebdo attack's. Journal of Advanced Research in Social Sciences and Humanities, 3(2), 68-75. doi:https://doi.org/10.26500/jarssh-03-2018 $-0204$

Renner, M., \& Taylor-Powell, E. (2003). Analyzing qualitative data (Unpublished master thesis). University of WisconsinExtension Cooperative Extension, Black River Falls, WI.

Seidman, S. A. (2008). Posters, propaganda, and persuasion in election campaigns around the world and through history. New York, NY: Peter Lang.

Shao, C., Ciampaglia, G. L., Varol, O., Flammini, A., \& Menczer, F. (2017). The spread of fake news by social bots. Nature Communications, 9(1), 96-104. doi:https://doi.org/10.1038/s41467-018-06930-7

Shoemaker, P. J., \& Vos, T. (2009). Gatekeeping theory. London, UK: Routledge.

Silverman, C., \& Singer-Vine, J. (2016). Most Americans who see fake news believe it, new survey says. Retrieved from https : // urlzs.com/i3HMo (Accessed on 1 April, 2017)

Simmons, R. G. (2017). Moving into adolescence: The impact of pubertal change and school context. London, UK: Routledge.

Wijetunge, M. T. N. (2016). Using communicative task-based speaking activities to enhance ESL speaking motivation in undergraduates. International Journal of Humanities, Arts and Social Sciences, 2(6), 203-208. doi:https://doi.org/ 10.20469/ijhss.2.20002-6 